\title{
Characterization of seed germination and protocorm development of Cyrtopodium glutiniferum (Orchidaceae) promoted by mycorrhizal fungi Epulorhiza spp.
}

\author{
Marlon Corrêa Pereira ${ }^{1 *}$, Diego Ismael Rocha ${ }^{2}$, Tomás Gomes Reis Veloso ${ }^{3}$, Olinto Liparini Pereira ${ }^{4}$, Dayana Maria Teodoro \\ Francino $^{5}$, Renata Maria Strozi Alves Meira ${ }^{6}$ and Maria Catarina Megumi Kasuya ${ }^{3}$
}

Received: April 07, 2015 Accepted: September 2, 2015

\begin{abstract}
Cyrtopodium glutiniferum is an endemic orchid of Brazil with potential medicinal and ornamental applications. As mycorrhizal fungi are essential for the initiation of the orchid life cycle, the aim of this study was to determine the strains of mycorrhizal fungi suitable for seed germination and protocorm development of C. glutiniferum and to characterize the symbiotic development of protocorms. Seeds of $C$. glutiniferum were inoculated with nine mycorrhizal fungi, Epulorhiza spp., Ceratorhiza spp., Rhizoctonia sp., originally isolated from Brazilian neotropical orchids. Only Epulorhiza isolates promoted seed germination and protocorm development. Three Epulorhiza isolates (M1, M6 =E. epiphytica, M20 = Epulorhiza sp.) promoted protocorm development until leaf production at 63 days. The protocorms are comprised of parenchyma cells delimited by a unistratified epidermis; the parenchyma cells of the upper part of the protocorms are smaller than those located more towards the base. Intact and digested pelotons were observed inside of protocorms implying that the seedlings were capable of mycotrophy. Additionally, the development of a bud primordium only occurred after colonization by fungus. This study suggests that C. glutiniferum has a preference for strains of Epulorhiza and that fungus digestion is essential to protocorm development.
\end{abstract}

Keywords: Ceratorhiza, Epulorhiza, orchid conservation, seedling production, symbiosis

\section{Introduction}

In nature, orchids consume mycorrhizal fungi as an energy source to prompt seed germination (Arditti 1992; Rasmussen 1995). The embryo develops and forms the protocorm, an achlorophyllous and heterotrophic stage of the orchid life cycle (Rasmussen \& Rasmussen 2009; Dearnaley et al. 2012). Mycorrhizal colonization and fungi consumption persist in orchid roots into adulthood, when the interaction serves an important role in orchid nutrition (Dearnaley 2007; Rasmussen \& Rasmussen 2009). Inoculation with mycorrhizal fungi has been applied to in vitro symbiotic seed germination and orchid cultivation (Pereira et al. 2011; Guimarães et al. 2013), with promising applications in the propagation of ornamental (Pereira et al. 2003a; 2005a), endangered (Zettler \& McInnis 1992; Zettler et al. 2007), and medicinal orchids (Chang \& Chou 2001; Tan et al. 2014).
Cyrtopodium glutiniferum is a species of neotropical orchid found in mountainous regions of the states of Minas Gerais and Rio de Janeiro in Brazil (Barros et al. 2015). It is terrestrial and sometimes litophytic, with an appealing flower suitable for horticulture (Caramaschi 2001). From the medicinal standpoint, the pseudobulbs contain the well-known anti-inflammatory compound glucomannan, and other potentially useful chemicals (Barreto \& Parente 2006). Given the ongoing threats to the natural habitats of C. glutiniferum, the ability to efficiently propagate this orchid would greatly enhance its conservation.

To date, very little has been published on the application of symbiotic techniques to Brazilian tropical orchids, and this is especially the case for taxa endemic to South America. The degree to which tropical orchids utilize fungi is unclear, but we have attempted to understand the orchidmycorrhizal association in our studies by isolating and identifying fungal symbionts (Pereira et al. 2003b; 2005b;

\footnotetext{
${ }^{1}$ Universidade Federal de Viçosa, Campus de Rio Paranaíba, BR 354, km 310, P.O. Box 22, 38810-000, Rio Paranaíba, MG, Brazil

${ }^{2}$ Instituto de Biociências, Universidade Federal de Goiás, Regional Jataí, 75.800-000, Jataí, GO, Brazil

${ }^{3}$ Departamento de Microbiologia, Universidade Federal de Viçosa, P.H. Rolfs, s/n, Campus Universitário, 36.570-000, Viçosa, MG, Brazil

${ }^{4}$ Departamento de Fitopatologia, Universidade Federal de Viçosa, P.H. Rolfs, s/n, Campus Universitário, 36.570-000, Viçosa, MG, Brazil

${ }^{5}$ Departamento de Ciências Biológicas, Universidade Federal dos Vales do Jequitinhonha e Mucuri, 39.100-000, Diamantina, MG, Brazil

${ }^{6}$ Departamento de Biologia Vegetal, Universidade Federal de Viçosa, P.H. Rolfs, s/n, 36.570-000, Viçosa, MG, Brazil

* Corresponding author: marlon.pereira@ufv.br
} 
c; 2009; 2014; Valadares et al. 2015), by germinating seeds of tropical orchids (Pereira et al. 2005a; 2011; Guimarães et al. 2013) and by characterizing protocorm development. Histological studies have also contributed to understanding the mechanisms involved in the mycorrhizal association (Arditti 1992).

It is common to use natural mycorrhizal fungi for in vitro seed germination (Pereira et al. 2005a; 2009). However, we have had no success in isolating mycorrhizal fungi from $C$. glutiniferum and other Cyrtopodium species (unpublished data). An alternative is to test mycorrhizal isolates obtained from other orchid species for their ability to prompt seed germination in C. glutiniferum, as proposed by Zettler (1997) and Zettler et al. (1999). However, it is very important to select a fungus that establishes an association with the specific orchid species in order to achieve better results with symbiotic methods (Esitken et al. 2005; Pereira et al. 2005a; Brundrett 2007; Pereira et al. 2011).

The aim of this study was to determine which mycorrhizal fungi are suitable for promoting seed germination and protocorm development of C. glutiniferum, and to characterize the symbiotic development of protocorms. We studied the effect of nine mycorrhizal fungus isolates, originally isolated from neotropical orchids from Brazil, and characterized the anatomy of different stages of protocorm development.

\section{Materials and methods}

\section{Fungal isolates}

Despite the fact that intact pelotons have been observed in anatomical sections of C. glutiniferum Raddi roots, attempts during 2002-2004 to isolate mycorrhiza fungi from this orchid species collected from its natural habitat in Rio de Janeiro State, yielded no success. So, nine isolates from the culture collection of orchid mycorrhizal fungi of the Departamento de Microbiologia, BIOAGRO, Universidade Federal de Viçosa (UFV), were selected for this study. The isolates represent the main mycorrhizal fungi of Brazilian orchids. The codes, identification and hosts of the isolates are, respectively: M1 - Epulorhiza epiphytica Pereira, Rollemberg et Kasuya, Epidendrum rigidum Jacq.; M5 - Epulorhiza repens (Bernard) Moore, Oeceoclades maculate (Lindley) Lindley; M6 - E. epiphytica, Polystachia concreta (Jacq.) Garay \& H.R. Sweet; M8 - Rhizoctonia sp., Gomesa crispa (Lindley) Klotzch \& Reichenbach f.; M9 - Rhizoctonia sp., Campylocentrum organense (Rchb. f.) Rolfe; M16 - Epulorhiza sp., Epidendrum secundum Jacq.; M19 - Rhizoctonia sp., Sarcoglottis sp.; M20 - Epulorhiza sp., Sophronitis milleri (Blumensch. ex Pabst) C. Berg \& M.W. Chase; M25 - Ceratorhiza sp., Catasetum sp. Theses isolates were previously obtained from the roots of Brazilian neotropical orchids (Pereira et al. 2003b; 2005a; b; c; Nogueira et al. 2005).
All isolates were stored in sterile distilled water at $4{ }^{\circ} \mathrm{C}$, and were reactivated in Petri dishes containing $25 \mathrm{~mL}$ of oatmeal-agar medium (OMA) - $2.5 \mathrm{~g}$ rolled oats, $7 \mathrm{~g}$ agar (pH 5.6), and $1 \mathrm{~L}$ tap water (Dixon 1987) - and incubated at $28^{\circ} \mathrm{C}$, for seven days.

\section{Seeds and symbiotic cultivation}

Seeds were harvested from mature, dry capsules of C. glutiniferum. A portion of $100 \mu \mathrm{g}$ of seeds were superficially disinfected by immersion for $10 \mathrm{~min}$ in $\mathrm{NaClO}$ with $2 \%$ active chlorine followed by three successive rinses in autoclave-sterilized distilled water, producing a final suspension volume of $50 \mathrm{~mL}$. The seed suspension was constantly shaken for homogeneity.

Three samples of $200 \mu \mathrm{L}$ of seed suspension were transferred onto Petri dishes containing $20 \mathrm{~mL}$ of modified OMA medium (4 g rolled oats, $7 \mathrm{~g}$ agar [pH 5.6], and $1 \mathrm{~L}$ distilled water) and spread over the medium surface with the use of a Drigalsky's loop. Five plates per isolate were each inoculated with a $1 \mathrm{~cm}^{3}$ oatmeal block comprising mycelia of the fungal isolate taken from the margin of the source colony. Five uninoculated plates constituted the control. The seed suspension was also spread over five plates containing 20 $\mathrm{mL}$ of Knudson C medium (Knudson 1922) for comparative purposes. The Petri dishes were sealed using PVC film and incubated at $25^{\circ} \mathrm{C}$ under a photoperiod $(38.20 \pm 10.42$ $\mu \mathrm{mol}$ photons $\mathrm{m}^{2} \mathrm{~s}^{-1}$ ) of $9 \mathrm{~h}$ of light. Plates were randomly distributed in the growth chamber.

\section{Seed germination, protocorm development and fungal colonization analysis}

After 63 days of incubation, all petri dishes were observed under an Olympus SZH10 stereomicroscope and the percentage of seeds germinating and protocorms developing were evaluated based on Zettler \& Hofer (1998), with some modifications. Each different developmental stage was assessed by means of a numerical index ranging from 0 to $6: 0=$ no germination; 1 = production of rhizoids; 2 = rupture of the testa by enlarged embryo; 3 $=$ appearance of promeristem; $4=$ appearance of the first leaf; $5=$ elongation of true leaf; and $6=$ elongation of true leaf and the formation of a branched root system. Total germination was calculated using the percentage of seeds in stages 1 through 6 . The growth index was estimated by the formula: $\mathrm{GI}=(\mathrm{N} 1+\mathrm{N} 2 \times 2+\mathrm{N} 3 \times 3+\mathrm{N} 4 \times 4+\mathrm{N} 5 \times 5)$ $\div(\mathrm{N} 0+\mathrm{N} 1+\mathrm{N} 2+\mathrm{N} 3+\mathrm{N} 4+\mathrm{N} 5)$, where $\mathrm{N} 0$ is the number of seeds in stage $0, \mathrm{~N} 1$ is the number of seeds in stage 1 , and so on (Otero et al. 2005). After an arcsine square-root transformation of the proportions, the total germination percentage and growth index data were submitted to an analysis of variance (ANOVA) and a means comparison by the Duncan test at $5 \%$ significance using the software Genes version 2007.0.0 (Cruz 2008). 
Protocorms were cleared with $\mathrm{KOH}$ and stained using Trypan blue (Phillips \& Hayman 1970), and samples were carefully mounted in lactoglycerol to observe fungal colonization using an Olympus BX50 light microscope.

The experiment was repeated to evaluate germination and developmental progress of seeds in association with isolates that promoted seed germination in the first experiment. Seeds of C. glutiniferum were co-inoculated with Epulorhiza isolates M1, M5, M6, M16, and M20, with five plates for each isolate, and incubated as described previously. Seeds were spread in the five inoculated plates with OMA, and without fungi for the control. Germination progress was assayed in all plates during periodical evaluations of 0,8 , 17,31 , and 66 days after incubation. Protocorm stages were determined using the numerical index described above. Percentage of C. glutiniferum in different development stages, total germination percentage and growth index were calculated and submitted to statistical analysis, as described above, for each evaluation period.

\section{Anatomical characterization of protocorms}

To anatomically characterize the development of protocorms, at least three at different developmental stages were fixed in $\mathrm{FAA}_{50}$ (formaldehyde, acetic acid and ethyl alcohol 50\%, 1:1:18 v/v) (Johansen 1940), dehydrated in an ethyl alcohol series and embedded in methacrylate (Historesin, Leica Instruments). Longitudinal and crossserial sections ( $5-\mu \mathrm{m}$ thick) were cut using a Leica RM2155 rotary microtome, and stained with toluidine blue ( $\mathrm{pH} 7.2)$. Examinations and photography were carried out using an Olympus AX-70TRF light microscope coupled with a U-photo camera system.

\section{Results and discussion}

After 63 days only isolates of the genus Epulorhiza (M1, M5, M6, M16 and M20) were found to promote C. glutiniferum seed germination (Figs. 1, 2A-B), with hyphae inside protocorm rhizoids (Fig. 2C) and intact and digested pelotons inside protocorm cells (Fig. 2D). In contrast, the isolates of Ceratorhiza, M8 and M25, and Rhizoctonia, M9 and M19, did not promote seed germination (Fig. 1). These results suggest the high specificity of this orchid to association with Epulorhiza. Orchid mycorrhizal associations have a high degree of plant-fungus specificity (Brundrett 2007). However, whether or not this species associates with Epulorhiza in situ remains unknown, which
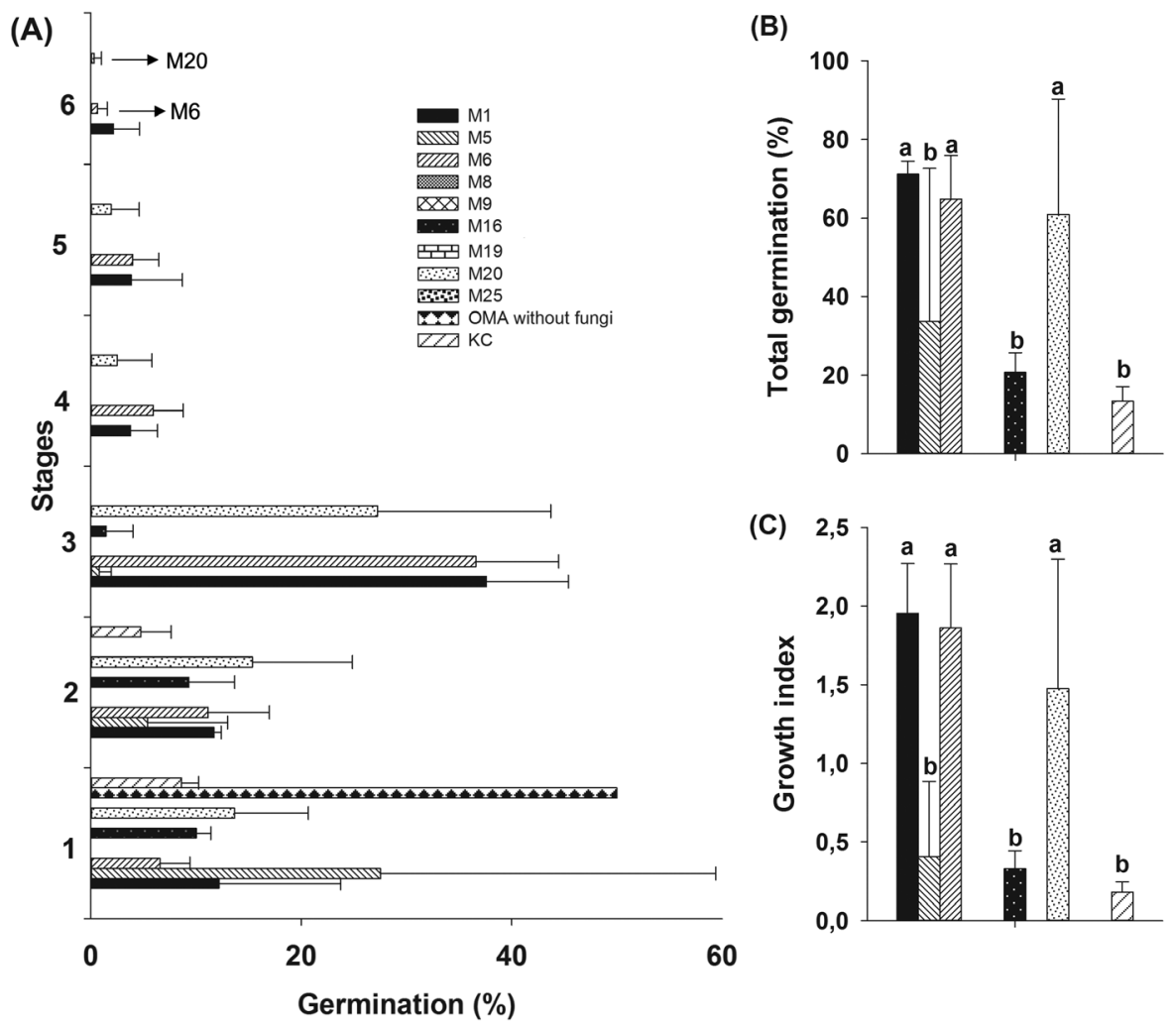

Figure 1. Cyrtopodium glutiniferum seed germination and protocorm development 63 days after seed incubation. (A) Protocorms in different developmental stages after sowing in: oatmeal medium (OMA) and inoculation with nine fungal isolates (M1, M5, M6, M8, M9, M16, M19, M20 e M25); OMA and Knudson C medium (KC) without fungal inoculation. Total germination (B) and growth index (C) calculated from seed germination and protocorm development data. Protocorm developmental stages: $0=$ no germination; $1=$ production of rhizoids; $2=$ rupture of the testa by enlarged embryo; $3=$ appearance of promeristem; $4=$ appearance of the first leaf; $5=$ elongation of true leaf; and $6=$ formation of branched root system. 

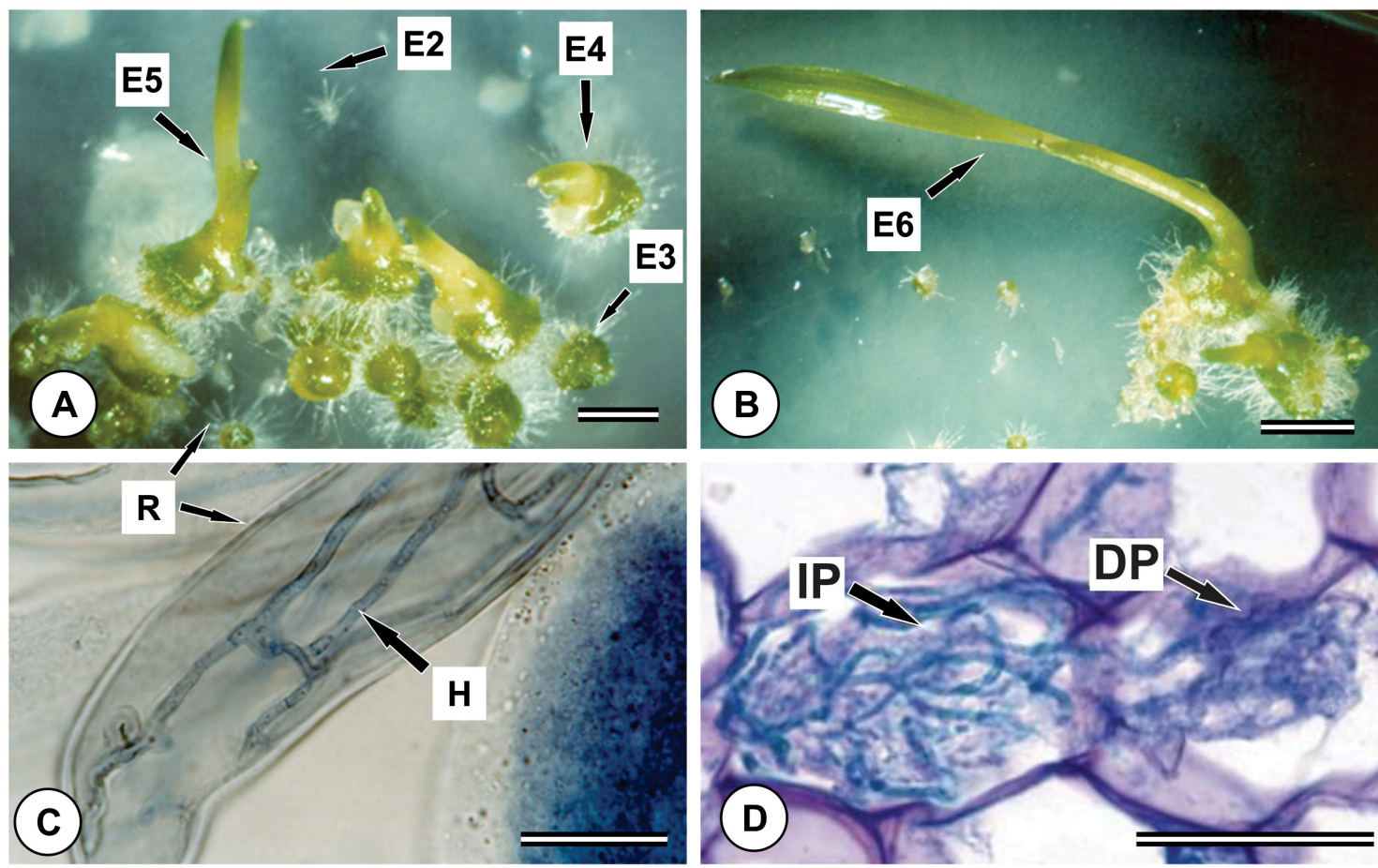

Figure 2. Protocorms and seedlings of Cyrtopodium glutiniferum and their colonization by mycorrhizal fungi 63 days after sowing. Development in association with the Epulorhiza isolates. A: M1; B: M20; C: Fungal hyphae (H) of Epulorhiza epiphytica colonizing a rhizoid (R); D: Intact (IP) and digested (DP) pelotons on the cortex of protocorms. Bars: $\mathbf{A}=1 \mathrm{~mm} ; \mathbf{B}=3 \mathrm{~mm} ; \mathbf{C}=40 \mu \mathrm{m} ; \mathbf{D}=50 \mu \mathrm{m} ; \mathrm{E} 2, \mathrm{E} 3$, E4, E5 and E6 boxes indicate stages 2, 3, 4, 5 and 6, respectively.

is further exacerbated by our previous inability to recover fungi from wild-collected material.

The failure of seeds to germinate in oatmeal medium without mycorrhizal fungi (Fig. 1) confirms the dependence of C. glutiniferum seeds on mycorrhizal fungi to initiate germination. In some orchids, the seed embryo can intumesce (stage 1, Pereira et al. 2011) or develop until the testa ruptures (stage 2, Peterson et al. 1998) in symbiotic medium without fungi, but they develop no further. This development is the consequence of water imbibition, and the inoculation of a suitable symbiont can allow for the continuation of seed development (Peterson et al. 1998). It is probable that mycorrhizal fungal infection is necessary for the C. glutiniferum embryo to absorb water and start its development (Yoder et al. 2000).

Our observation of intact and digested pelotons in wild plants (unpublished data), and in protocorms and seedlings cultured in vitro (Figs. 2C-D, 3A-B), argue in support of mycotrophy playing a significant role in C. glutiniferum. Peloton degradation is a main nutrient source for seed development, since orchid seeds lack endosperm and have little nutrient reserves in embryo cells (Peterson et al. 1998). Furthermore, even adult plants obtain organic carbon and inorganic nutrients from the digestion of fungi (Cameron et al. 2006; 2007; 2008). Therefore, mycotrophy not only supports $C$. glutiniferum development during seed germination and protocorm development, but also assists in providing nutrition for the seedling and its growth (Guimarães et al 2013).
We observed that Epulorhiza spp. mycorrhizal fungi isolated from another orchid host were capable of promoting the germination and development of C. glutiniferum (Fig. 1), which is in accordance with the results of Zettler \& McInnis (1993) and Zettler et al. (1999). As we did not isolate the natural symbiont of C. glutiniferum, an alternative attempt was to inoculate mycorrhizal fungi obtained from other Brazilian orchids. For this we performed a screening test by inoculating with fungi of a variety of genera obtained from different orchids. The identification of Epulorhiza spp. as a suitable symbiont of C. glutinifurum permitted a second series of experiments on seed germination and seedling acclimatization, as performed by Guimarães et al. (2013). These authors selected the Epulorhiza sp. isolate that had the best results in promoting seed germination of E. secundum (Pereira et al. 2011).

Seedlings developed to stage 6 (first leaf and a branched root system; Fig. 2B), when inoculated with isolates M1, M6 and M20 (Fig. 1A). Even a few protocorms reached stage 6 in these isolates, protocorms reaching late stages (1-5) can continue developing until advanced stages and form a seedling. These isolates had the highest, and statistically equivalent, total germination percentages and growth indexes (Figs. 1B$\mathrm{C}$ ), above that observed in asymbiotic medium (Knudson C, Figs. 1B-C). These results suggest that M1, M6 and M20 have good potential for use in the propagation of this orchid, since a high germination percentage and seedlings reaching stage 6 demonstrate that a large number of saplings can be 
developed and transferred to ex vitro conditions faster than would be possible using an asymbiotic medium. Although isolates M5 and M16 were able to induce seed germination of C. glutiniferum, they were the less effective because the germination percentage was low and protocorms only developed the promeristem (stage 3; Figs. 1A, 2A). Zettler et al. (2000), utilizing three different Epulorhiza spp. isolates for symbiotic seed germination of the threatened species Platanthera integra observed that despite the fact that all isolates were effective at inducing seed germination and protocorm establishment, only one isolate, Epulorhiza inquilina, isolated from another orchid was highly effective. Based on our success with fungi from other orchid species, and given the lack of knowledge of the natural symbiont, we advocate using Epulorhiza strains to propagate C. glutiniferum until other isolates can be obtained.

During the evaluation of germination and development we observed different seed responses in the different isolates tested (Tab. 1). In the presence of M1, M6, M16 and M20 isolates, seed germination started 17 days after inoculation. During this period protocorms in stage 3 were obtained in the presence of M1 (1\%) and M16 (less than 1\%). M6 and M20 promoted development until stage 2 (less than $1 \%$ for both). At 31 days, protocorms in stage 3 were observed in the presence of M1 (39\%), M6 (4\%) and M16 (6\%), while M20 promoted the protocorm development until stage $2(35 \%)$. At 66 days, protocorms in stage 3 were observed in the presence of M5 and M20 (53\%). Protocorms in stage 6 were observed in M1 (5\%), M6 (less than 1\%) and M16 (less than 1\%) during the same period. At 17, 31 and 66 days, M1 exhibited a high germination percentage and the highest growth index (Tab. 1), which suggests that protocorms develop faster in association with M1 than with the other isolates. Therefore, isolate M1,
E. epiphytica, has the best potential to be used to propagate C. glutiniferum.

After seed germination and disruption of the tegument, the embryo forms a conical-shaped, light-green colored protocorm (stage 2 - Fig. 2A). In this early stage of protocorm development (stage 2), longitudinal sections of these structures showed that they consisted of a set of parenchyma cells covered by a unistratified epidermis, making it possible to establish differences in cell size and volume (Fig. 3A-B). In the chalazal region (top), the parenchymatic cells had a smaller volume when compared to the other protocorm cells (Fig. 3A-B). In the micropylar region (basal), the parenchymatic cells were vacuolated and rhizoids (unicellular thichomes) were present (Fig. 3B). A high level of mitotic activity was also observed in the central region of the protocorm, associated with provascular tissue development (Fig. 3B). The morphology and anatomomy of these protocorms, thus, coincides closely with the general description of other orchid protocorms, such as those of Dactylorhiza spp. (Rasmussen 1995; Cribb 1999; Kraus et al. 2006).

Intact and degraded pelotons were observed in the basal cells of protocorms at stage 2 (Figs. 2D, 3A-B). Uetake et al. (1997) observed this same colonization pattern in protocorms obtained by symbiotic germination with Rhizoctonia fungi. However, this pattern is not exclusive to protocorms germinated with Rhizoctonia, but has also been recently observed in protocorms germinated with non-Rhizoctonia fungi. The fact that fungal colonization is absent from aerial parts of plants further explains the restriction of fungal colonization to basal cells, and demonstrates that even in early development stages orchids exert control over their symbiotic fungi. However, physiological factors that control this pattern of colonization remain poorly understood (Rasmussen \& Rasmussen 2009).

Table 1. Total germination and growth index produced by the orchid mycorrhizal fungi Epulorhiza spp. (isolates M1, M5, M6, M16 and M20) at 17, 31 and 66 days after inoculation. At zero and eight days seed germination was not observed.

\begin{tabular}{|c|c|c|c|c|c|}
\hline \multirow{2}{*}{ Days } & \multicolumn{5}{|c|}{ Total germination (\%) } \\
\hline & M1 & M5 & M6 & M16 & M20 \\
\hline 17 & $42.49 \pm 22.15 \mathbf{B ~ a}$ & $0 \pm 0 \mathbf{B ~ c}$ & $3.64 \pm 5.02 \mathrm{~B} \mathrm{bc}$ & $11.7 \pm 12.99 \mathrm{C} \mathbf{a b}$ & $13.52 \pm 20.74 \mathbf{B ~ b}$ \\
\hline 31 & $77.37 \pm 3.47 \mathbf{A ~ a}$ & $0 \pm 0$ B c & $62.58 \pm 14.35 \mathrm{~A} \mathrm{a}$ & $32.88 \pm 14.58 \mathbf{B} \mathbf{b}$ & $72.18 \pm 5.51 \mathrm{~A} \mathrm{a}$ \\
\hline \multirow[t]{3}{*}{66} & $86.38 \pm 3.31 \mathrm{~A} \mathrm{a}$ & $51.18 \pm 27.33 \mathbf{A ~ b}$ & $75.46 \pm 3.36 \mathrm{~A} \mathrm{a}$ & $62.89 \pm 1.55 \mathrm{~A} \mathrm{ab}$ & $86.67 \pm 1.47 \mathrm{~A} \mathrm{a}$ \\
\hline & \multicolumn{5}{|c|}{ Growth Index } \\
\hline & M1 & M5 & M6 & M16 & M20 \\
\hline 17 & $0.61 \pm 0.34 \mathbf{C ~ a}$ & $0 \pm 0 \mathbf{B ~ c}$ & $0.04 \pm 0.05 \mathrm{Cc}$ & $0.17 \pm 0.17 \mathbf{B}$ ab & $0.14 \pm 0.2 \mathbf{C ~ b c}$ \\
\hline 31 & $1.84 \pm 0.27 \mathbf{B ~ a ~}$ & $0 \pm 0 \mathbf{B ~ d}$ & $0.95 \pm 0.36 \mathbf{B} \mathbf{b c}$ & $0.59 \pm 0.28 \mathrm{Ac}$ & $1.08 \pm 0.17 \mathbf{B ~ b}$ \\
\hline 66 & $2.88 \pm 0.02 \mathbf{A ~ a ~}$ & $0.63 \pm 0.3 \mathrm{~A} \mathrm{c}$ & $1.97 \pm 0.23 \mathbf{A ~ b}$ & $0.97 \pm 0.1 \mathbf{A ~ c}$ & $2.17 \pm 0.04 \mathbf{A ~ a b}$ \\
\hline
\end{tabular}

Data subjected to analysis of variance and the Duncan mean test at $5 \%$ significance level, obtained after an arcsine square root-transformation of the proportions. The means followed by the same lowercase letters in the line and by the same uppercase letters in the column are statistically equal among each other. 
Differentiating rhizoids were observed only in the micropylar region (basal) of protocorms (Fig. 3B). These structures are, generally, related to initial fixation by protocorms of epiphytic species and to nutrient absorption (Arditti 1992). It has also been suggested that these rhizoids are a preferred route for hyphae penetration. According Steinford et al. (2010), depending on the species of orchid, hyphal penetration can occur in suspensor cells, rhizomes

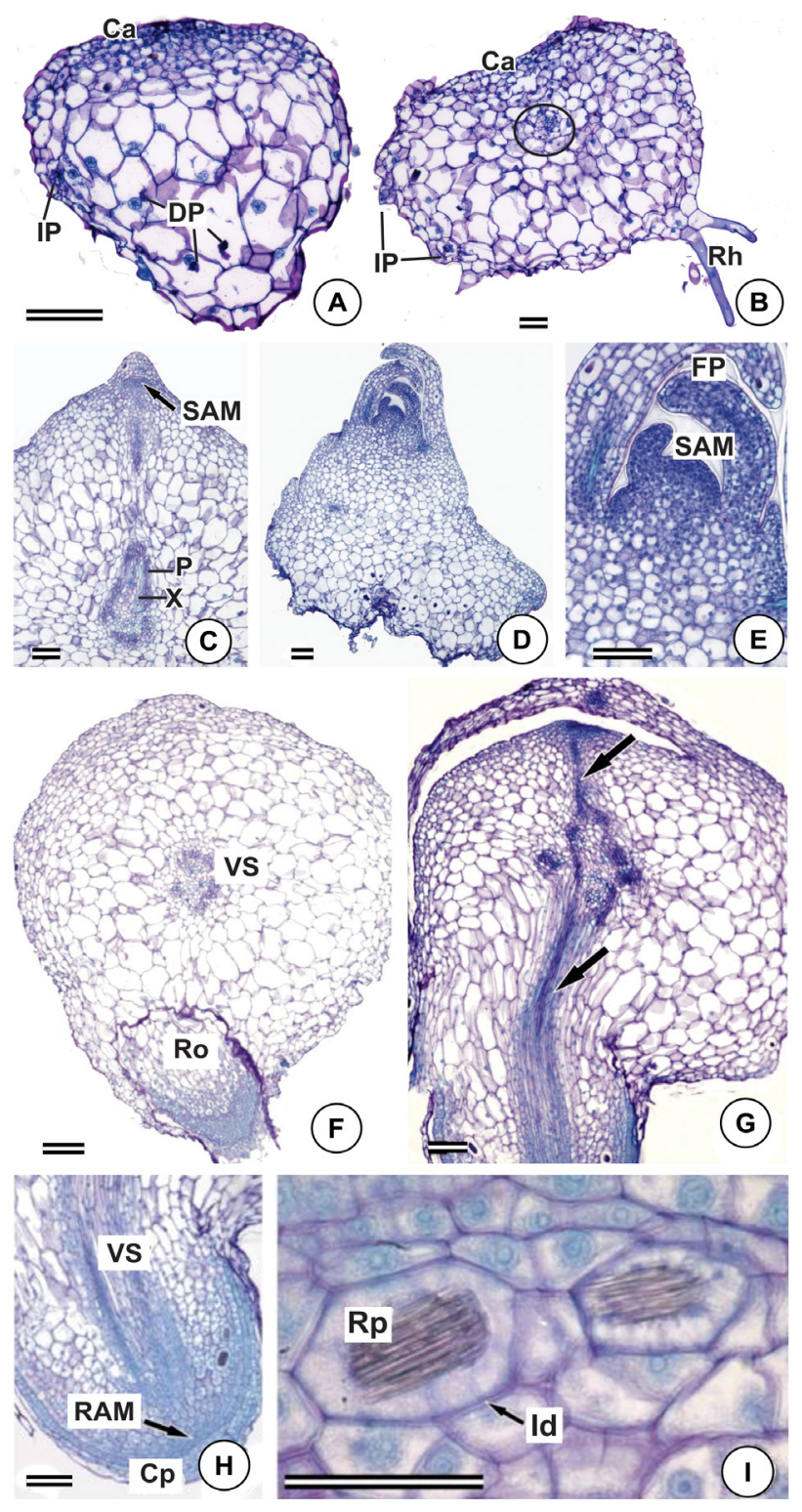

Figure 3. Protocorms of Cyrtopodium glutiniferum cultivated symbiotically with Epulorhiza epiphytica. Longitudinal sections. A-B: Early developmental stages of protocorms; Note the development of provascular tissue in the central region of the protocorm (circle); C-E: Development of shoot apical meristem (SAM) and leaf primodia (FP); F: Emergence of the first root (Ro); G: Procambial strands which extend through the protocorm (arrows); $\mathrm{H}$ : Detail of the root showing the root apical meristem (RAM); I: Idioblast (Id) containing raphide crystals (Rp). Abrv.: (Ca) Chalazal region; (Cp) Cap; (DP) Digested pelotons; (IP) Intact pelotons; (P) Phloem; (Rh) Rhizoid; (VS) Vascular system; (X) Xylem. Bars = $\mathrm{A}-\mathrm{H}=100 \mu \mathrm{m} ; \mathrm{I}=50 \mu \mathrm{m}$ and epidermal hairs, in addition to rhizoids. The restriction of the formation of rhizoids to the basal region of the protocorm avoids an excess of penetration routes, and will consequently allow the healthy development of tissues (Wright \& Guest 2005).

We observed the beginning of the development of the shoot apical meristem (SAM) in the chalazal region of protocorms at 17 days of culture in the presence of isolates M1 and M16 (stage 3; Fig. 3C). The cells of the SAM had a small volume and a dense cytoplasmic content and exhibited a high level of mitotic activity. In the central region, the vascular system was differentiated and xylem and phloem were seen weaving through the cortical region of the protocorm, reaching the layers of the SAM (Fig. 3D). The formation of a bud primordium occurred only after colonization by fungus. It has been previously suggested that mycorrhizal association may provide energy for protocorm development (Rasmussen 1995; Wright \& Guest 2005).

It was possible to see a typical SAM with the first leaf primordia at 66 days, characteristic of developmental stage 4 (Fig. 3D-E). At this stage we also noted the presence of pelotons in the micropylar region (Fig. 3D). This demonstrates that the fungal isolates are compatible with C. glutiniferum, since it has been reported that in incompatible associations fungal colonization is spread-out and reaches the meristem, thereby preventing cellular differentiation (Clements 1998; Wright \& Guest 2005).

Stage 6 was observed at 66 days, when the formation of the first root (Fig. 3F-I) and several leaf primordia were observed. This root had an endogenous origin (Fig. 3F) and its vascular system was connected to those of the SAM (Fig. 3G-H). Idioblasts containing raphids were present in the root and no pelotons or fungal hyphae were observed in the cells of this plant organ (Fig. 3H- I).

Our study demonstrated that Epulorhiza spp. are suitable mycorrhizal fungi for propagating C. glutiniferum. The Epulorhiza isolates displayed different potentials to promote seed germination and protocorm development. Consequently, it is essential to perform a screening test to identify the most efficient isolate. The obtainment of seedlings in advanced stage (stage 6) suggests that is possible to introduce seedlings ex vitro with higher survival rates, as demonstrated by Guimarães et al. (2013). Here we describe anatomically the development of the protocorm of C. glutiniferum from seed to seedling, and confirm the maintenance of an association with the mycorrhizal fungi during this period. While we advocate that symbiotic seed germination may become a useful conservation tool in the propagation of $C$. glutiniferum, our technique should not be viewed as a replacement for techniques that do not incorporate fungi (asymbiotic germination). Additional research, especially involving symbiotic germination, fungal recovery, characterization, and preservation, should be adopted on a wider scale to further enlighten the conservation of tropical orchids threatened with extinction. 


\section{Acknowledgements}

We are very grateful to the Instituto Estadual de Florestas (IEF) for the license to collect orchid seedlings and seed samples from biological conservation areas in Brazil; Dr. R. W. Barreto and Dr. D.W. Barreto who provided C. glutiniferum mature capsules; Dr. Mariana Fonseca Machado for helping with sectioning; and the anonymous reviewers for their helpful suggestions. This work is part of the project "Biodiversity of mycorrhizal fungi associated with the roots of Brazilian orchids", financed by FAPEMIG (CAG 708/02) and CNPq (470443/06-5).

\section{References}

Arditti J. 1992. Fundamentals of orchid biology. New York, John Wiley \& Sons.

Barreto DW, Parente JP. 2006. Chemical properties and biological activity of a polysaccharide from Cyrtopodium cardiochilum. Carbohydrate Polymers 64: 287-291.

Barros F, Vinhos F, Rodrigues VT, et al. 2015. Orchidaceae in Lista de Espécies da Flora do Brasil. Jardim Botânico do Rio de Janeiro. $<$ http://floradobrasil.jbrj.gov.br/jabot/floradobrasil/FB31819>. 01 Abr. 2015

Brundrett MC. 2007. Scientific approaches to Australian temperate terrestrial orchid conservation. Australian Journal of Botany 55: 293-307.

Cameron DD, Johnson I, Leake JR, Read DJ. 2007. Mycorrhizal acquisition of inorganic phosphorus by the green-leaved terrestrial orchid Goodyera repens. Annals of Botany 99: 831-834.

Cameron DD, Johnson I, Leake JR, Read DJ. 2008. Giving and receiving: measuring the carbon cost of mycorrhizas in the green orchid, Goodyera repens. New Phytologyst 180: 176-184.

Cameron DD, Leake JR, Read DJ. 2006. Mutualistic mycorrhiza in orchids: evidence from plant-fungus carbon and nitrogen transfers in the green-leaved terrestrial orchid Goodyera repens. New Phytologist 171: 405-416.

Caramaschi GMCL. 2001. Propagação in vitro de Cyrtopodium spp. (Orchidaceae). Msc. thesis, Universidade de Brasília, Brazil.

Chang DCN, Chou LC. 2001. Seed germination of Habenaria discolor var. dawsoniana and the use of mycorrhizae. Symbiosis 30: 29-40.

Clements MA. 1988. Orchid mycorrhizal associations. Lindleyana 3: 73-86.

Cribb PJ. 1999. Morphology. In: Pridgeon AM, Cribb PJ, Chase MW. (eds). Genera Orchidacearum: general introduction, Apostasioideae, Cypripedioideae. Oxford, Oxford University Press.

Cruz CD. 2008. Programa Genes: Diversidade genética. Viçosa, Editora UFV.

Dearnaley JDW. 2007. Further advances in orchid mycorrhizal research. Mycorrhiza 17: 475-486.

Dearnaley JDW, Martos F, Selosse MA. 2012. Orchid mycorrhizas: molecular ecology, physiology, evolution and conservation aspects. In: Hock B. (ed.) The Mycota IX: Fungal associations. 2nd edn. Springer, Berlin Heidelberg.

Dixon K. 1987. Raising terrestrial orchids from seed. In: Harris WK. (ed). Modern orchid growing for pleasure and profit. Adelaide, Orchid Club of South Australia Inc.

Esitken A, Ercisli S, Eken C. 2005. Effects of mycorrhiza isolates on symbiotic germination of terrestrial orchids (Orchis palustris Jacq. and Serapias vomeracea subsp. vomeracea (Burm. f.) Briq.) in Turkey. Symbiosis 38: 59-68.

Guimarães FAR, Pereira MC, Felício CS, et al. 2013. Symbiotic propagation of seedlings of Cyrtopodium glutiniferum Raddi (Orchidaceae). Acta Botanica Brasilica 27: 590-596.

Johansen DA. 1940. Plant microtechnique. New York, Mcgraw-Hill Book.

Knudson L. 1922. Nonsymbiotic germination of orchid seed. Botanical Gazette 73: 1-25.
Kraus JB, Kerbauy GB, Monteiro WR. 2006. Desenvolvimento de protocormos de Catasetum pileatum Rchb. F. in vitro: aspectos estruturais e conceituais. Hoehnea 33: 177-184.

Nogueira RE, Pereira OL, Kasuya MCM, Lanna MC, Mendonça M. 2005. Fungos micorrízicos associados e orquídeas em campos rupestres na Região do Quadrilátero Ferrífero, Minas Gerais, Brasil. Acta Botanica Brasilica 19: 417-424.

Otero JT, Bayman P, Ackerman JD. 2005. Variation im mycorrhizal performace en the epiphytic orchid Tolumnia variegate in vitro: the potential for natural selection. Evolutionary Ecology 19: 29-43.

Pereira MC, Coelho IS, Valadares RBS, et al. 2014. Morphological and molecular characterization of Tulasnella spp. fungi isolated from the roots of Epidendrum secundum, a widespread Brazilian orchid. Symbiosis 62: 111-121.

Pereira MC, Kasuya MCM, Pereira OL, Costa MD, Rocha RB. 2009. Diversidade de fungos micorrízicos Epulorhiza spp. isolados de Epidendrum secundum (Orchidaceae). Revista Brasileira de Ciência do Solo 33: 1187-1197.

Pereira MC, Torres DP, Guimaraes FAR, Pereira OL, Kasuya MC. 2011. Germinação de sementes e desenvolvimento de protocormos de Epidendrum secundum Jacq. (Orchidaceae) em associação com fungos micorrízicos do gênero Epulorhiza. Acta Botanica Brasilica 25: 534-541.

Pereira OL, Kasuya MCM, Borges AC, Araújo EF. 2005b. Morphological and molecular characterization of mycorrhizal fungi isolated from neotropical orchids in Brazil. Canadian Journal of Botany 83: 54-65.

Pereira OL, Kasuya MCM, Rollemberg CL, Borges AC. 2005a. Indução in vitro da germinação de sementes de Oncidium flexuosum (Orchidaceae) por fungos micorrízicos rizoctonióides. Revista Brasileira de Ciência do Solo 29: 199-206.

Pereira OL, Kasuya MCM, Rollemberg CL, Chaer GM. 2005c. Isolamento e identificação de fungos micorrízicos rizoctonióides associados a três espécies de orquídeas epífitas neotropicais no Brasil. Revista Brasileira de Ciência do Solo 29: 191-197.

Pereira OL, Rollemberg CL, Borges AC, Matsuoka K, Kasuya MCM. 2003b. Epulorhiza epiphytica sp. nov. isolated from mycorrhizal roots of epiphytic orchids in Brazil. Mycoscience 44: 153-155.

Pereira OL, Rollemberg CL, Kasuya MCM. 2003a. Association des mycorhizies dans les orchidees - perspectives d'utilisation dans les programmes de propagation symbiotique. Orchidees 55: 24-27.

Peterson RL, Uetake Y, Zelmer C. 1998. Fungal symbioses with orchid protocorms. Symbiosis 25: 29-55.

Phillips JM, Hayman DS. 1970. Improved procedure for clearing roots and staining parasitic and vesicular-arbuscular mycorrhizal fungi for rapid assessment of infection. Transactions of the British Mycological Society 55: 158-161.

Rasmussen HN. 1995. Terrestrial orchids: from seeds to mycotrophic plant. Cambridge, Cambridge University Press.

Rasmussen HN, Rasmussen FN. 2009. Orchid mycorrhiza: implications of a mycophagous life style. Oikos 118: 334-345.

Steinfort U, Verdugo G, Besoain X, Cisterna M. 2010. Mycorrhizal association and symbiotic germination of the terrestrial orchid Bipinnula fimbriata (Poepp.) Johnst (Orchidaceae). Flora 205: 811-817.

Tan XM, Wang CL, Chen XM, et al. 2014. In vitro seed germination and seedling growth of an endangered epiphytic orchid, Dendrobium officinale, endemic to China using mycorrhizal fungi (Tulasnella sp.). Scientia Horticulturae 165: 62-68.

Uetake Y, Farquhar ML, Peterson RL. 1997. Changes in microtubule arrays in symbiotic orchid protocorms during fungal colonization and senescence. New Phytologist 135: 701-709.

Valadares RBS, Otero JT, Pereira MC, Cardoso EJBN. 2015. The epiphytic orchids Ionopsis utricularioides and Psygmorchis pusilla associate with different Ceratobasidium lineages at Valle del Cauca, Colombia. Acta Botanica Brasilica 29: 40-44.

Wright M, Guest D. 2005. Development of mycorrhizal associations in Caladenia tentaculata. Selbyana 26: 114-124.

Yoder JA, Zettler LW, Stewart SL. 2000. Water requirements of terrestrial and epiphytic orchid seeds and seedling, and evidence for water uptake by means of micotrophy. Plant Science 156: 145-150. 
Zettler LW. 1997. Terrestrial orchid conservation by symbiotic seed germination: techniques and perspectives. Selbyana 18: 188-194.

Zettler LW, Burkhead JC, Marshall JA. 1999. Use of a mycorrhizal fungus from Epidendrum conopseum to germinate seed of Encyclia tampensis in vitro. Lindleyana 14: 102-105.

Zettler LW, Hofer CJ. 1998. Propagation of the little club-spur orchid (Platanthera clavellata) by symbiotic seed germination and its ecological implications. Environmental and Experimental Botany 39: 189-195.

Zettler LW, Mcinnis TM. 1992. Propagation of Platanthera integrilabia (Correll) Luer, an endangered terrestrial orchid, through symbiotic seed germination. Lindleyana 7: 154-161.
Zettler LW, Mcinnis TM. 1993. Symbiotic seed germination and development of Spiranthes cernua and Goodyera pubenscens (Orchidaceae: Spiranthoideae). Lindleyana 8: 155-162.

Zettler LZ, Poulter SB, Mcdonald KI, Stewart SL. 2007. Conservationdriven propagation of an epiphytic orchid (Epidendrum nocturnum) with a mycorrhizal fungus. HortSciense 42: 135-139.

Zettler LW, Sunley JA, Delaney TW. 2000. Symbiotic seed germination of an orchid in decline (Platanthera integra) from the Green Swamp, North Carolina. Castanea 65: 207-212. 